Ingrid Lund

Universitetet i Agder

Anne Helgeland

Sørlandets Sykehus

Velibor Bobo Kovac

Universitetet i Agder

DOI: http://dx.doi.org/10.5617/adno.4691

\title{
På vei mot en ny forståelse av mobbing i et folkehelseperspektiv
}

\section{Sammendrag}

Helse og utdanning er flettet sammen. God helse fremmer laring og utvikling, og utdanning er viktig for fremtidsutsikter, sosial posisjon og helse som voksen. For at barn og unge skal erfare skolekonteksten som en helsefremmende kontekst, er det avgjørende at lceringsmiljøet er inkluderende. Mobbing er en av de sterkeste indikatorene på manglende inkludering. Artikkelens hensikt er tredelt: 1) Rette et kritisk søkelys mot den etablerte forståelsen av mobbing, der aggresjon, intensjonalitet, tid og makt er sentrale faktorer, 2) løfte frem nyere perspektiver, med vekt på mobbing som sammensatte sosiale prosesser, der voksne er de ansvarlige og betydningen av å høre til og medvirke i et fellesskap er det sentrale, 3) beskrive de praktiske implikasjoner som denne forståelsen av mobbing kan føre til i skolen, sett i et folkehelseperspektiv.

Nøkkelord: inkluderende læringsmiljø, mobbing, skolekultur, ledelse.

\section{The work fighting bullying from a public health perspective}

\begin{abstract}
Health and education are intertwined in the sense that good health promotes learning and development, whilst education is also important for future prospects, social position, and health in adulthood. In order that children and young people perceive their school context as health promoting, it is crucial that the learning environment is inclusive. Bullying is one of the strongest possible indicators that there is a lack of inclusion. This article's purpose has three aspects: 1) Directing a critical focus towards the established understanding of bullying, in which aggression, intentionality, time, and power are central
\end{abstract}


factors, and where the point of departure is that this understanding can hinder the mastery of life, 2) Highlighting recent perspectives with an emphasis on bullying as complex social processes where the adults are responsible and the significance of listening to - and taking part in - fellowship is central, and 3) Describing the practical implications which this understanding of bullying might lead to in schools from a public health perspective.

Key words: inclusive learning environment; bullying; school culture; leadership.

\section{Introduksjon}

Skolen er en viktig ramme i barn og unges liv. I Norge går 629275 barn på skolen (Statistisk Sentralbyrå, 2017). Hvordan barn og unge har det i skolen, er derfor et naturlig folkehelsespørsmål. Folkehelse er et omfattende begrep som i folkehelselovens paragraf 3 blir definert som "befolkningens helsetilstand og hvordan helsen fordeler seg i en befolkning” (Lovdata, 2012). Folkehelsearbeid blir i samme paragraf beskrevet som "samfunnets innsats for å påvirke faktorer som direkte eller indirekte fremmer befolkningens helse og trivsel”. Det handler om forebyggende tiltak som fremmer fysisk og psykisk helse.

Folkehelseinstituttet beskriver påvirkningsfaktorene for helse blir av som en årsakskjede som strekker seg fra generelle samfunnsforhold, som politikk og økonomistyring, til individets oppvekstsvilkår, som hjemmet og skolen, som er de mest sentrale kontekstene for barn og unge. Alle disse påvirkningsfaktorene virker igjen inn på den enkeltes biologiske og genetiske kjennetegn, beskyttelsesfaktorer og sårbarheter (Rutter, 2000).

I denne påvirkningskjeden er skolen en sentral del av barn og unges liv. Både nasjonal og internasjonal forskning fremhever at skolen bør ha en sentral, aktiv og integrerende rolle i helsefremmende arbeid (Drugli, 2012; Milkie \& Warner, 2011; Rutter, 2000). Helse og utdanning er flettet sammen gjennom at god helse fremmer læring og utvikling, samtidig som at utdanning er viktig for fremtidsutsikter, sosial posisjon og helse som voksen (Herrman, Saxena \& Moodie, 2005). Folkehelsebegrepet kan knyttes tett opp mot livsmestringsbegrepet, som av Helsedirektoratet defineres som "å kunne forstå og ha mulighet til å påvirke avgjørende faktorer for mestring av eget liv" (Helsedirektoratet, 2017). I fagfornyelsen av Kunnskapsløftet er folkehelse og livsmestring ett av tre tverrfaglige temaer, ifølge Stortingsmelding nr. 28 (20152016). Her understrekes det også at skolen som arena for sosial tilhørighet, ferdigheter og holdninger er avgjørende for barn og unges opplevelse av mestring og livsglede, følelse av egenverd og god psykisk helse.

For at barn og unge skal erfare skolekonteksten som en helsefremmende kontekst der livsmestringsopplevelser er en sentral del av skolehverdagen, er det 
avgjørende at læringsmiljøet er inkluderende. Både nasjonal og internasjonal forskning understreker betydningen av et inkluderende læringsmiljø. Med dette menes de betingelser i skolen som fremmer barn og unges helse, trivsel, emosjonelle, sosiale og kognitive utvikling (Aviles, Anderson \& Davila, 2006; Cobb-Roberts, Dorn \& Shircliffe, 2006).

Denne delen av læreplanverket beskriver det forpliktende grunnsynet som skal prege og støtte den pedagogiske praksisen i skolen. Læreplanverket består av en generell del, prinsipper for opplæringen, læreplaner for ulike fag og fagog timefordeling. Dette er forskrifter til opplæringslova og skal styre opplæringen i Norge. I den nye læreplanen er folkehelse og livsmestring med som sentrale deler av det forpliktende grunnsynet som skal prege all pedagogisk praksis. I tillegg kommer kjernetemaer knyttet til mobbing, slik som håndtering av følelser, respekt og tilhørighet. Her står det under pkt. 2.6.1:

Elevene skal øve på å sette ord på og håndtere sine egne følelser, relasjoner og handlingsmønstre. De skal lære å sette grenser og respektere andres, utvikle et positivt selvbilde, og delta i et faglig og sosialt fellesskap som gir tilhørighet.

(Folkehelseinstituttet, 2014, s. 13)

Sammenhengen mellom livsmestring, læringsmiljø og mobbing blir også trukket frem i Stortingsmelding nr. 28:

Det vil være naturlig for skolene å se opplæringen i livsmestring i sammenheng med utvikling av skolefellesskapet, elevenes psykososiale miljø og arbeidet mot mobbing. Det kan bidra til økt sammenheng mellom opplæringen i fagene og arbeidet med læringsmiljøet.

(Stortingsmelding nr. 28, s. 39).

Arbeidet for et trygt psykososialt miljø, med vekt på mobbing, knyttes her tett sammen med faglig utvikling, elevenes opplevelse av mestring og fellesskap. Både nasjonal og internasjonal forskning underbygger sammenhengene ved å fremheve konsekvensene av mobbing for barn og unges helse og livskvalitet. Fosse (2006) fant at nesten $50 \%$ av voksne som søkte hjelp ved en psykiatrisk poliklinikk, hadde vært utsatt for mobbing i skolealder. Jo mer alvorlig mobbingen hadde vært, desto mer alvorlige og langvarige var både angst- og depresjonsdiagnosene. I en stor meta-analyse av 29 forskjellige studier blir det dokumentert at elever som ble mobbet i skolealder, hadde i gjennomsnitt dobbelt så stor risiko for depresjon og andre relaterte problemer ved oppfølging syv år senere (Ttofi, Farrington, Lösel \& Loeber, 2011). Sammenhengen mellom det å bli utsatt for mobbing og graden av det som blir definert som internaliserende problematikk, som tilbaketrekking, somatiske plager, depresjon og angst, er også påvirket av genetiske faktorer (Arseneault, Walsch, Trzesniewski, Newcombe, Caspi \& Moffit, 2006). Dette viser jo at sammenhengene ikke kun kan forklares ved genetisk sårbarhet, men at mobbing er en reell risikofaktor for 
psykiske helseplager. Det betyr at der hvor mobbing skjer, vil helsen svekkes og livsmestringsopplevelsene få dårlige kår.

Hensikten med denne artikkelen er tredelt: 1) Rette et kritisk søkelys mot den etablerte forståelsen av mobbing, der aggresjon, intensjonalitet, tid og makt er sentrale faktorer, med utgangspunkt $\mathrm{i}$ at denne forståelsen kan hindre livsmestring, 2) løfte frem nyere perspektiver, med vekt på mobbing som sammensatte sosiale prosesser der voksne er de ansvarlige og betydningen av å høre til og medvirke i et fellesskap er det sentrale, 3) beskrive de praktiske implikasjoner som denne forståelsen av mobbing kan føre til i skolen i et folkehelseperspektiv.

\section{Etablerte forståelser av mobbing}

Det finnes ulike forståelser og diskusjoner knyttet til bruken av begrepet mobbing. Ett av de begrepene som oftest knyttes til mobbing, er "krenkelse". Dette begrepet blir også brukt i Elevundersøkelsen for 2013-2016. Elevundersøkelsen er en av Utdanningsdirektoratets nettbaserte brukerundersøkelser, som gir norske elever i 7. og 10. klasse og i 1. klasse på videregående muligheten til å si hva de mener om forhold som er viktige for at de skal lære og trives i skolen. I denne undersøkelsen blir Gladdens m.fl. (2014) sin kategorisering brukt: 1) direkte verbale 2) relasjonelle og 3) fysiske krenkelser. Denne kategoriseringen blir også anvendt for å beskrive mobbebegrepet. I tillegg kommer digital mobbing inn som en del av den verbale og relasjonelle mobbingen. I enkelte undersøkelser blir den definert som en egen kategori. Mobbing er krenkelse, og krenkelser kan være mobbing, og det kan være utfordrende å skille begrepene fra hverandre (Wendelborg, 2016, s. 1416). Mobbebegrepet står sterkt, til tross for diskusjonene om hvilke begreper som kan utvide forståelsen, eller eventuelt erstatte begrepet.

Den svenske mobbeforskeren Dan Olweus (1997), som regnes som en pioner innen mobbelitteraturen, var en av de første som beskrev og operasjonaliserte fenomenet mobbing. Olweus definerer mobbing slik: "En person er mobbet eller plaget når han eller hun, gjentatte ganger og over en viss tid blir utsatt for negative handlinger fra en eller flere personer” (Olweus, 1997, s. 17). Negative handlinger er i følge Olweus knyttet til situasjoner når en påfører, eller prøver å påføre, en annen person skade eller ubehag. I denne forståelsen er aggresjon som vises gjennom fysisk vold, samt handlinger med verbal aggresjon, eksplisitt angitt. I tillegg skiller Olweus mellom direkte og indirekte mobbing. Direkte mobbing er aktive, observerbare angrep på mobbeofferet, mens indirekte mobbing innebærer isolering og sosial utestengning (Olweus, 1997). Olweus legger i sin definisjon også vekt på frekvensen og tidsaspektet, og viser til at mobbing kan utøves av både enkeltpersoner og grupper. Aggressivitet som en viktig definisjonskomponent kan også merkes i forslaget fra Roland, som sier at 
"Mobbing er langvarig vold, psykisk og/eller fysisk, rettet mot et offer og utført av enkeltpersoner eller grupper” (Roland, 1983, s. 12). Roland legger større vekt på aggresjonsaspektet enn Olweus, og han har en definisjon som kan oppfattes mer innsnevret enn Olweus sin.

Oppsummert kan vi si at den etablerte forståelsen av mobbing understreker at mobbing handler om at (1) noen skader noen andre, enten psykisk eller fysisk, (2) handlingen er intensjonell, (3) handlingen gjentas over tid, (4) det er ubalanse i maktforholdet mellom aktører. Barn og unge blir ofte tildelt roller som mobber og offer, og forklaringer og tiltak rettes i hovedsak mot den enkelte deltaker eller deltakerne i mobbesituasjonen. Faren blir dermed større for at de kontekstuelle aspektene og de voksnes ansvar for tilretteleggingen av et inkluderende læringsmiljø nedtones. Her kan også det enkelte barn som utsetter andre for mobbing, bli definert som "aggressiv" og som "plageren", og handlingene definert som intensjonelle, som hos Roland:"Plagerne vil sjelden gå til plutselig angrep, men heller bruke litt tid på å posisjonere seg” (2007, s. 75). Rolletildelingen som mobber, her "plager", er stigmatiserende, og det enkelte barns skyld blir en del av den forståelsen det handles ut ifra, med hensyn til både tiltak og oppfølging.

Andre definisjoner i feltet betrakter i større grad mobbing som et resultat av sosial samhandling. Den definisjonen som aller tydeligst vektlegger de sosiale prosessers betydning for å forstå mobbing, er de danske forskerne Schott og Søndergaard (2014). De beskriver mobbing som kompliserte, sosiale prosesser:

Bullying is an intensification of the processes of marginalization that occur in the context of dynamics of inclusion/exclusion, which shape groups. Bullying happens when physical, social or symbolic exclusion becomes extreme, regardless of whether such exclusion is experienced and/or intended.

(Schott \& Søndergaard, 2014, s. 13-14)

En styrke med dette perspektivet er eksplisitt oppmerksomhet mot mobbing som et sosialt fenomen som oppstår mellom mennesker og rammer menneskelige sosiale behov. I det en flytter søkelyset fra individuell aggresjon som en personbasert egenskap til kontekstuelle faktorer, som for eksempel barns oppvekstsvilkår i hjem, barnehage, skole og fritid, skaper en samtidig mulighet for å identifisere kontekstuelle utfordringer og opprettholdende faktorer som innrammer mobbeprosessen. Det betyr ikke at barnets individuelle forutsetninger ikke er en del av de sosiale prosessene, men at hovedfokuset med tanke på tiltak og endring rettes mot de relasjonelle og kontekstuelle faktorene (Kofoed \& Søndergaard, 2009). 


\section{Mot en utvidet forståelse av mobbing}

I denne artikkelen bygger vi videre på en merkbar trend $\mathrm{i}$ internasjonal forskning som i større grad enn tidligere legger vekt på sosiale aspekter av forståelsen av mobbing (Schott \& Søndergaard, 2014, s. 13-14). Idet vi fremmer en ny forståelse av mobbing i skolen, erkjenner vi at en definisjon ikke kan romme alt. Det er nå engang slik at noe havner i skyggen når en retter lyskaster mot noe spesifikt som en ønsker å få frem.

Vi definerer mobbing på følgende måte:

Mobbing av barn er handlinger fra voksne og/eller barn som hindrer opplevelsen av å høre til, å være en betydningsfull person i fellesskapet og muligheten til medvirkning.

Tidligere definisjoner av mobbing er designet hovedsakelig for å måle forekomster av mobbing. I denne forståelsen blir søkelyset flyttet fra antall ganger, tid, aggresjon, makt og intensjonalitet og over til voksnes handlinger og grunnleggende behov som blir hindret der mobbing skjer. Et viktig aspekt $\mathrm{i}$ vår definisjon er at vi ikke trekker et skarpt skille mellom den som mobber og den som er mobbet. Vi argumenterer for at tradisjonelle definisjoner som i utgangspunktet tildeler roller som mobber og offer, fører til en uheldig posisjonering hos alle aktører når det gjelder håndtering av mobbesituasjoner. Til tross for at den nye forståelsen kan kritiseres for å være mer vag og mindre målbar, er den anvendelig i praksis. Økt oppmerksomhet på grunnleggende menneskelige behov som rammes, danner et godt utgangspunkt for å avdekke, håndtere, stoppe, følge opp og - til syvende og sist - forstå på en helhetlig måte dype følelser som eksisterer mellom ulike parter i en mobbekonflikt. Når en unngår å tildele faste roller som skyldig og offer, har en større sjanse til å oppnå forsoning og en endring som fører til mer likeverdige relasjoner. I tillegg kan den nye forståelsen bidra til å få frem en del situasjoner mellom mennesker som er delvis skjult eller ikke fanget opp av dimensjoner som aggressivitet, frekvens, intensjonalitet og asymmetriske forhold. Dette inkluderer digital mobbing, men også situasjoner hvor dype, såre følelser er bagatellisert på grunn av mangel på objektive målbare kriterier (f.eks. søskenmobbing, mobbing innenfor samme vennegjeng, mobbing skjult bak voksen autoritet, onde humoristiske bemerkninger og lignende). Det forebyggende arbeidet og tiltak som iverksettes i skolen, vil da fokusere på mellommenneskelige relasjoner, voksenrollen, organisasjonskultur, strukturer og handlingsplaner, og løfte seg opp fra et individperspektiv til et systemperspektiv. Det ultimate målet er å fremme en forståelse av mobbing som fører til at skolen og den enkelte lærer legger til rette for et inkluderende læringsmiljø og for økt livskvalitet for alle barn og unge i skolen. Økt fokus på menneskelige behov og subjektivitet kan føre til at elevene i større grad kjenner seg som en betydningsfull deltaker i fellesskapet der den enkelte elevs stemme har en betydning. Vår definisjon inneholder tre 
kjerneelementer som er sentrale for å forstå, forebygge, stoppe, håndtere og følge opp mobbing:

1. Også voksne mobber

2. Barnets subjektivitet og rett til medvirkning

3. Barnets grunnleggende behov for tilhørighet

Vi ønsker å drøfte disse tre temaene opp mot folkehelse og livsmestring for barn og unge i skolen, og se hvilke praktiske implikasjoner dette vil kunne ha for skolens praksis.

\section{Også voksne mobber}

Nasjonale og internasjonale undersøkelser viser at omfanget av barn som mobber andre barn, er langt større enn voksne som mobber barn. Elevundersøkelsen fra 2016 viser at 4,6 \% av elevene blir mobbet av andre elever to til tre ganger i måneden eller oftere. Internasjonale undersøkelser viser tall helt opp mot 14 \% (Fekkes, 2005; Modecki, Minchin, Harbaugh, Guerra \& Runions, 2014). Når barn mobber barn i skolen, er det de voksne som er de ansvarlige. Det er de som skal forebygge, avdekke, stoppe, håndtere og følge opp mobbing.

Når vi velger å fremheve voksne som mobbere i skolen, er det fordi dette fenomenet er en del av mobbingens vesen i skolen, og det er underkommunisert og svært alvorlig. Barn og unge i skolen burde være trygge på at de voksne som arbeider der, ikke utsetter dem for mobbing, men den norske Elevundersøkelsen fra 2016 viser at 1,8 \% av elevene opplevde seg mobbet av voksne på skolen den siste måneden. I og med at 431778 elever deltok i undersøkelsen, betyr det at 7772 elever i norsk skole oppgir at voksne mobber dem.

I Elevundersøkelsene fra 2013 til 2016 har det også blitt stilt spørsmål om ulike typer krenkelser. Her er også voksne på skolen en av kategoriene. Svarene viser at i alle krenkelseskategoriene bekrefter elever at også de voksne utsetter dem for krenkelser. For eksempel opplever opp mot 11,8 \% av elevene at de blir truet, og av disse er 9,3 \% av de voksne på skolen. Av de 11,8 \% svarte også $23,5 \%$ at "ingen voksne gjorde noe som hjelper meg”. Det finnes også internasjonal forskning som bekrefter at lærere mobber elever. I en britisk undersøkelse besvarte 116 lærere i grunnskolen en anonym undersøkelse, der 40 $\%$ sier at de har mobbet elever (Twemlow, 2005). Argumenter som har blitt brukt mot de høye tallene fra Elevundersøkelsen, der elever rapporterer at mobbing fra lærere skjer, er at noen elever og elevgrupper er så sårbare at de tolker negativt den minste bevegelse og det minste ord som ikke var ment krenkende. "Skylden" kan lett bli lagt på elevene, der atferd og personlighetskarakteristikker blir en sentral del av årsaksforklaringene til mobbingen. I et folkehelseperspektiv må barn og unges helse og livsmestringsmuligheter alltid forstås i lys av flere faktorer, eller for å anvende 
folkehelseinstituttets begrep: i en "påvirkningskjede" (jf. innledningen). Sårbarhet henger selvsagt sammen med biologiske og genetiske forhold, men må også forstås sammen med kontekstuelle og kulturelle sårbarhetsfaktorer. Her kan mobbing fra lærere bli en påvirkningsfaktor som øker den enkeltes sårbarhet, noe som igjen hindrer livsmestring.

Vi vet at noen elever og elevgrupper er mer sårbare enn andre. Blant annet er barn og unge som har utfordrende oppvekstsvilkår og/eller fysiske og psykiske plager, mer sårbare enn andre elever (Anderman, 2002; Beardslee, Chien \& Bell, 2011). Når vi forklarer at mobbing skjer på grunn av sårbarhet hos den enkelte elev, er vi tilbake til å rette forklaringene for mobbing mot individet, med fokus på offerrollen. Hvis en forstår sårbarhet som en naturlig del av det å være menneske, at sårbarhet er mer fremtredende i enkeltsituasjoner, under gitte livsbetingelser og kan vise seg gjennom ulike atferdsuttrykk, da kan forståelsen av sårbarhet utvides fra individ til samspillets muligheter og utfordringer.

Undersøkelser viser også at mens elever og lærere vurderer ganske likt når det gjelder omfang av konflikter mellom elever, så anser lærere at det er langt færre konflikter mellom lærere og elever enn det elevene selv mener (Delfabbro Winefield, Trainor, Dollar, Anderson, Metzer \& Hammarstrom, 2006; Hanssen, 1998). Resultatene fra disse undersøkelsene kan en tolke som at lærere ikke fanger opp negative opplevelser som elevene knytter til relasjoner mellom lærere og elever. Dette kan igjen føre til bagatellisering og hindre at tiltak iverksettes.

\section{Implikasjoner for praksis i arbeidet mot voksne som mobber}

NOU 2015:2 har et eget kapittel som omhandler ansatte ved skoler som mobber elever (kap. 8, s. 107-110). Her blir den enkelte lærers plikt og ansvar som rollemodell fremhevet, samtidig som lærerkollegiets og ledelsens ansvar løftes frem i arbeidet mot mobbing. Mobbing er handlinger som krever at noen ser, tør å si ifra og følger opp at endring skjer. Det forutsetter en ledelse som har klare rutiner når mobbing meldes, og at disse følges opp. Det handler om kollegaer som tør å si ifra, og den enkelte lærers kapasitet og vilje til å se på egen praksis ut ifra elevenes subjektive opplevelser. Når mobbing skjer, utfordres skolen på så mange nivåer: skolen som organisasjon, skolekultur, ledelse, relasjoner og den enkelte lærers møte med eleven(e) (Møller m.fl., 2005).

Twemlow og hans kollegaer har i sine undersøkelser (2005; 2006) blant annet også drøftet skolelederes medvirkning til at mobbing fra lærere opprettholdes. De konkluderer blant annet med at unnvikenhet, konfliktskyhet, manglende rapporteringssystemer for denne formen for mobbing og for dårlig og utydelig ledelse fører til at mobbing fra lærere fortsetter. Dette betyr at skolen kontinuerlig må arbeide med gode evaluerings- og rapporteringssystemer som fanger opp mobbing fra lærere. Da blir en nødvendig og selvsagt konsekvens at tiltak iverksettes og at ledelsen får en særskilt viktig rolle i både forebygging, avdekking, håndtering og oppfølging (Rigby, 2007). 
Skolekulturen inneholder normer som sier noe om hvilke handlinger som er akseptable og hvilke som ikke er det. Normer omfatter all atferd som forventes, aksepteres eller støttes av en gruppe, enten normen er uttalt eller ikke (Bergem, 1998). Normer er i mange tilfeller knyttet til verdier, i den forstand at de foreskriver hvordan en konkret skal handle i bestemte situasjoner for å virkeliggjøre en eller flere verdier (Bang, 2013). Verdiene og normene som lever i den enkelte skolekulturen, vil igjen prege den enkeltes virkelighetsoppfatninger idet ulike mobbesituasjoner oppstår. Der lærere utsetter elever for mobbing, vil det ofte være ulike virkelighetsoppfatninger av hva som har skjedd i mobbesituasjonen. Studier der barn og unge blir intervjuet om mobbing, viser at ulike virkelighetsoppfatninger er grunnlag for manglende tiltak og oppfølging ifølge elevene selv (Lund, Ertesvåg \& Roland, 2010; Frisen, Holmquist \& Oscarsson, 2008)). Ifølge Bang (2013) er virkelighetsoppfatninger i en organisasjon oppfatninger som medlemmene utvikler sammen og tar for gitt. Etter hvert som ansatte med lignende oppfatninger jobber sammen, ser hvordan kollegaer oppfører seg og hvilke konsekvenser ulike handlinger og hendelser får, utvikles felles erfaringer som gir grunnlag for fremveksten av et sett av kollektive oppfatninger av virkeligheten. Dette kan være alt fra å definere enkeltelever, vurderinger av enkelthendelser, antakelser av hva som vil skje, til årsaksforklaringer og en felles forståelse av hva som skal og kan gjøres, og hva som ikke nytter. Innenfor én og samme skole kan det eksistere flere ulike sett av felles verdier, normer og virkelighetsoppfatninger. Samtidig er det ofte én kultur som dominerer virksomhetens innhold og form (Kaufmann \& Kaufmann, 2015). Noe av verdigrunnlaget for skolekulturen vil være nedfelt i lover, regler og rutiner, men skolekulturen vil også ha sitt grunnlag i de uskrevne reglene og normene som gjelder ved skolen, og som viser seg i skolehverdagen. Det betyr at hvis en skal arbeide aktivt for å forebygge mobbing fra voksne i skolen, må det arbeides aktivt på alle nivåer i skolen mot en felles visjon og felles mål (Vaillancourt, 2003). Felles verdier legger grunnlaget for sosiale normer, som igjen danner handlingsregler for hva som er riktig og hva som er galt. Da vil det være tydelig og helt konkret uttalt hvilket ansvar og handlingsplikt den enkelte ansatte har når en ser elever blir mobbet. For at dette skal kunne skje, er en avhengig av en skoleledelse som fremmer en kultur med orden og positiv atferd, som legger til rette for at skolens innhold og struktur har en kontinuitet, tydelighet, trygghet, forutsigbarhet og åpen kommunikasjon i alle ledd.

\section{Barnets subjektivitet og rett til medvirkning}

Barneombudet gir innspill når Folkehelseinstituttet utgir folkehelserapportene sine. I 2014 kom de blant annet med dette innspillet om betydningen av barns medvirkning $\mathrm{i}$ et folkehelseperspektiv: "Mestring = Folkehelse [...] Barn og unges medvirkning gir også en 'added value' som i et folkehelseperspektiv ikke kan undervurderes" (Barneombudet, 2014, s. 5). 
Barns opplevelse av mestring er avhengig av trygge relasjoner, forutsigbare voksne og en skolekultur der strukturene gjenspeiler inkludering som en overordnet verdi. Først da kan den enkelte elev medvirke i fellesskapet og oppleve seg som en betydningsfull deltaker. Der mobbing skjer, følger frykt, uro og ensomhet (Søndergaard, 2012). Og med frykt, uro og ensomhet er muligheten for mestringsopplevelser minimalisert. For at mestring skal skje, må barnets subjektive opplevelse av det som er utfordrende bli tatt imot av voksne. Skolens håndtering av mobbing er tydelige for alle. Rolleavklaringene er tydelige der rektor som øverste leder har et hovedansvar for at fastlagte rutiner følges og evalueres. Barnet må vite at den subjektive opplevelsen av mobbing ikke bagatelliseres eller glemmes i en hektisk skolehverdag. Uten en grunnleggende trygghet på at den voksne tar barnets perspektiver på alvor, vil mestring og medvirkning ha dårlige kår.

I Djupedal-utvalgets rapport (NOU 2015:2) står det følgende om utvalgets bekymring for at barn og unge ikke blir trodd når de forteller om mobbing:

Utvalget er bekymret for dette og mener at det er behov for å tydeliggjøre at det er elevens subjektive opplevelse som er det avgjørende for om elever er krenket eller ikke.

(Kunnskapsdepartementet, 2015, s. 211)

Djupedal-utvalgets rapport ble fulgt opp blant annet gjennom en ny utgave av opplæringslovens paragraf 9 A. Denne ble iverksatt fra 1. august 2017. De største endringene er lovfestet krav til nulltoleranse mot mobbing, en tydeligere aktivitetsplikt og en håndhevingsordning der tvangsmulkt kan brukes mot skoleeiere som ikke følger opp mobbing. I prakis betyr dette at rektor skal informeres når elever forteller om mobbing, og hans/hennes plikt til konkret handling, skriftlig plan og evaluering er skjerpet gjennom aktivitets- og handlingsplikten. Dette betyr at nytt lovverk styrker elevens rett til å bli hørt og tatt på alvor. Det står blant annet i paragraf 9 A-4 Aktivitetsplikt for å sikre at elevar har eit trygt og godt psykososialt skolemiljø følgende: "Skolen skal sørgje for at involverte elevar blir høyrde. Kva som er best for elevane, skal vere eit grunnleggjande omsyn i skolen sitt arbeid."

Elevenes ve og vel er her fremhevet som en overordnet verdi knyttet til deres rett til å bli hørt. Når elever blir hørt, styrkes den enkeltes opplevelse av medvirkning, og subjektiviteten styrkes. Det avgjørende for subjektivitetens livsvilkår er hvordan andre forstår, tolker og tar imot våre initiativ. Når barn eller ungdom utsettes for mobbing, blir det da ikke sentralt i vår forståelse om handlingene er utført intensjonelt eller ei, hvor lenge dette varer, eller antall ganger. I vår forståelse av mobbing står elevens subjektive opplevelse helt sentralt. Dette perspektivet vektlegges også i den nye opplæringslova gjennom å fokusere på de voksnes plikt til å lytte og handle med bakgrunn i elevens subjektive opplevelse av mobbingen. 
Voksnes plikt til å lytte å handle er tett forbundet med barn og unges livsmestring. Der voksne i skolen tar elevers subjektive opplevelser på alvor når mobbing skjer, vil barn og unges erfaringer med mobbing kunne gi dem økt tro og tillit til voksne, samt mot og styrke til å møte nye utfordringer.

Livsmestring for barn og unge er å utvikle ferdigheter og tilegne seg praktisk kunnskap som hjelper den enkelte til å håndtere medgang, motgang, personlige utfordringer, alvorlige hendelser, endringer og konflikter på en best mulig måte. Å skape en trygghet og tro på egne evner til å mestre også i fremtiden.

(Landsrådet for Norges barne- og ungdomsorganisasjoner, 2017, s. 9)

Når barn og unge i skolen skal lære seg å håndtere motgang, personlige utfordringer, alvorlige hendelser og konflikter som mobbing, er de avhengige av de voksnes evne og vilje til å ta imot deres subjektive erfaringer. Det barn lærer av unnvikenhet og bagatellisering fra voksne, er at subjektive erfaringer og opplevelser ikke betyr noe for andre, at det ikke nytter å dele. Konsekvensene av denne type erfaringer kan føre til lavt selvbilde, manglende mestringstro, depresjon og angst (Rutter, 1997), og forsterker de negative konsekvensene av mobbing.

\section{Implikasjoner for praksis med barnets subjektivitet og rett til medvirkning i fokus}

I læreplanverket for Kunnskapsløftet fra 2006 (LK06) er det understreket hvordan gruppearbeid og elevrådsarbeid er en sentral faktor for elevers medvirkning i arbeidet mot mobbing. I den egne læreplanen for elevrådsarbeid står det følgende:

Gjennom arbeid i elevgrupper og ved deltakelse i påvirknings- og beslutningsprosesser, deriblant arbeid i elevråd, skal faget bidra til at elevene utvikler egen evne til å uttrykke selvstendige meninger og sin evne og vilje til å samarbeide. Slik kan faget fremme utviklingen av et inkluderende læringsmiljø som er fritt for mobbing og preget av trygghet og sosial tilhørighet.

(LK 06 s. 47)

For at barn skal møtes på egne initiativ på en måte som styrker subjektiviteten deres, og som bidrar til livsmestring og god psykisk helse, er det nødvendig at voksne bidrar med å skape gode vilkår for barnet. Dette kan gjøres ved å gi dem påvirkningsmuligheter i beslutningsinstanser, slik som elevråd, der meningene deres kan komme tydelig frem. Der har de også mulighet for å påvirke reglementer og være i dialog med skolens ansatte om hva som fremmer et inkluderende læringsmiljø som er fritt for mobbing. Barnekomiteen (Sandberg, 2011, s. 80) vektlegger barns rett til å bli hørt som særdeles viktig for å utvikle barn og unge til aktive samfunnsborgere. Det krever at voksne møter barn som 
meningsytrende subjekter og anerkjenner deres opplevelser ved å lytte, bekrefte og være nysgjerrige i møte med deres historier.

Den tyske professoren og filosofen Axel Honneth (2008) sin forståelse av anerkjennelse har perspektiver som er nyttige som bakgrunn for å ivareta barns subjektive opplevelser og rett til medvirkning i praksis.

- A se den andre, til forskjell fra å ikke se (usynliggjøre). Her snakker vi om et grunnleggende syn på voksenrollen som en rolle som er har ansvar og som skal se, som ikke kan velge å se bort når mobbing skjer. Det betyr å se elevenes ulike behov i ulike situasjoner. Det kan være behov for støtte til å mestre i ulike situasjoner, slik at den sosiale og emosjonelle kompetansen styrkes og eleven blir mer robust i møte med motgang (jf. livsmestring).

- $\AA$ bekrefte individets positive egenskaper. Da blir negativ definisjon av barn og unge erstattet med et positivt fokus som bygger på et barnesyn som løfter opp det kompetente og samarbeidende barnet (Juul \& Jensen, 2002).

- A anerkjenne annerledeshet. Barn er forskjellige og har ulike utfordringer. I inkluderende læringsmiljøer er dette en av de viktigste grunnverdiene. Det betyr at elever og lærere anerkjenner verdier og levesett som er forskjellig fra egne verdier og levesett. Her er det grunnleggende verdier som fremkommer i fagplanen for samfunnsfag for 7. klasse. Der står det blant annet at elevene skal kunne "samtale om kjærlighet og respekt, variasjon i seksuell orientering og samliv og familie, og diskutere konsekvenser av manglende respekt for ulikheter. Dette er et eksempel på hvordan enkelte fag kan løfte frem en tematikk som kan være forebyggende for mobbing. Gjennom tekst, dialog, kunst, film og musikk kan dette være et tverrfaglig tema med små og store prosjekter i fag som norsk, mat og helse, kunst og håndverk, engelsk, KRLE og musikk.

- $\AA$ ha en inkluderende holdning i det sosiale fellesskap. Der de voksne i skolen har en overordnet inkluderende målsetting for sin pedagogiske praksis, vil alt som skjer på skolen bli preget av dette. Da vil organisasjonens strukturer og innhold legge føringer for hvordan den enkelte lærer skal forholde seg til elevers subjektive opplevelse av mobbing. Det er rutiner som alle er kjent med, og som danner grunnlaget for de holdninger og handlinger som vises i praksis. Det betyr også at den som utsetter de andre for mobbing, trenger støtte og veiledning, slik at den kan inkluderes i fellesskapet på en god måte og oppleve mestring og medvirkning som kommer fellesskapet til gode. Der lærerne viser dette gjennom sine holdninger og handlinger, vil den pedagogiske praksis 
gjennomsyres av dette i de enkelte fag, og eleven vil parallelt med faglig kompetanseheving også kunne utvikle sosial og emosjonell kompetanse. I norsk er det for eksempel i veiledningen til læreplanen understreket under fagets egenart at faget er et dannelsesfag. Videre står det at elevene skal rustes til demokratiske prosesser. Alle fagene har "å kunne bruke digitale verktøy” som grunnleggende ferdighet. I norskfaget er det et særskilt fokus på den kritiske bruken av digitale kilder. Her vil digital mobbing kunne være et tema som kan knyttes sammen med KRLE og samfunnsfag. Etiske spørsmål om respekt for mangfold og demokratiske prinsipper kan drøftes opp imot den enkeltes ansvar og plikt i en digitalisert hverdag.

- $\AA$ ha samsvar mellom holdninger og handlinger. Her vil bruksverdiene være det avgjørende: Det som elevene hver dag ser, hører og kjenner i møte med den voksne og den pedagogiske praksis. De store ordene har liten verdi uten at de synes i praksis. Da vil livsmestring under utfordrende situasjoner der mobbing skjer, komme til å synes ved at den voksne handler og følger opp det som er formidlet gjennom elevens subjektive opplevelse. Samsvaret mellom holdninger og handlinger skal også være en del av den opplæringen elevene får i fag som for eksempel KRLE. I læreplanverket for faget står det følgende:

Faget skal bidra til dialog mellom mennesker med ulik oppfatning av tros- og livssynsspørsmål. Dette innebærer respekt for religiøse verdier, menneskerettigheter og menneskerettighetenes etiske verdier.

(Kunnskapsdepartementet, 2005, s. 3)

Her vil prosjekter som fremmer ulike livssyn og verdier, kunne være grunnlaget for viktige dialoger mellom elevene og mellom lærere og elever. Da vil holdninger og handlinger komme tydelig frem. I samarbeid med fag som norsk, musikk og mat og helse vil dette kunne være med på å utvide elevers holdninger, som igjen kan føre til inkluderende handlinger (Andreassen, 2016).

\section{Barnets grunnleggende behov for tilhørighet}

Behovet for tilhørighet er et grunnleggende, menneskelig behov som kan knyttes til mobbing. Der mobbing skjer, vil det være noen som er utenfor, som ikke hører til i et fellesskap. Behovet for å høre til er grundig analysert i forskningslitteratur, og argumentene for dens betydning er allment aksepterte (Baumeister \& Leary, 1995). Generelt refererer behovet for tilhørighet til en rekke handlinger hvor individuelle og/eller gruppeforbindelser initieres, opprettholdes og brytes med tanke på å oppnå sosial kontakt med andre mennesker (se oversikt i Kovac, 2016). Mennesker er fra fødselen av programmert til å forme forskjellige typer sosial tilknytning. I tillegg 
gjenkjenner, definerer og stadig overvåker mennesker sosiale omgivelser for å finne ut om de er en del av fellesskapet og hvem som er og ikke er en del av fellesskapet (Leary, 2011). Kvaliteten på sosiale relasjoner et menneske har, er en god indikator på generell psykososial funksjon, helse og opplevd lykke (Gardner, Gabriel \& Diekman, 2000) som igjen har avgjørende betydning for livskvalitet og livsmestring.

Det generelle behovet for tilhørighet er i litteraturen ofte analysert i lys av interpersonelle prosesser og gruppeprosesser som er sentrale for menneskelig utvikling. Eksempelvis er tilhørighet ofte knyttet til tilknytningsteori (Cassidy \& Shaver, 2008). Historisk sett har tilknytningsteori gjennomgått en utvikling. Fra å beskrive samhandling mellom barn og omsorgsgiveren deres, (Bowlby, 1969, 1973; Ainsworth, 1967),omfatter tilknytningsteori nå også analyser av sosial fungering i et livslangt perspektiv (Slade, 2009; se også Obegi \& Berant, 2009). I tillegg har kvalitet og nærhet i sosiale relasjoner vist seg til å være viktig for barnet med tanke på identitetsforming og harmonisk utvikling (Orlofsky, Marcia, \& Lesser, 1973). Behovet for tilhørighet viser seg også gjennom barnets ønske om å føle seg verdsatt som et gruppemedlem av en vennegjeng i skolekonteksten. Der mobbing skjer, hindres opplevelsen av å kjenne seg som en betydningsfull deltaker i et fellesskap, og tilhørighetsopplevelsen svekkes. Som beskrevet tidligere, er opplevelsen av å høre til en livslang prosess, men grunnlaget dannes ofte i barndommen. De gode erfaringene som barnet får gjennom hele oppveksten, blir ofte transformert i generaliserte erfaringer som utgjør en del av den totale selvforståelsen. På samme måte blir også opplevelser knyttet til mobbing en del av selvforståelsen, men da på en negativ måte som kan få store negative konsekvenser for barn og unges livskvalitet (Sourander et al., 2009; Ttofi et al., 2011).

\section{Implikasjoner for praksis med bakgrunn i elevenes grunnleggende behov for tilhørighet}

Når elever utsettes for mobbing, har de en tendens til å isolere seg fra jevnaldrende. Johansen og Flygare (2013) fant i sin undersøkelse av dem som hadde blitt utsatt for mobbing over tid, at relasjonene og tilhørigheten til medelevene ble svekket. Tilhørighet er avhengig av et inkluderende fellesskap der den enkelte kan være trygg nok til å prøve og feile uten å bli utsatt for krenkelser fra andre. For å oppnå et inkluderende fellesskap i skolen må undervisningens mål og innhold tilrettelegges i praksis på en måte som inkluderer alle elevene som aktive deltakere i skolens faglige og sosiale innhold. Det må utvikles et felles tilhørighetsforhold til klassens virksomhet. I dette arbeidet blir god klasseledelse helt sentralt. Klasseledelse er godt dokumentert i nasjonal og internasjonal forskning opp mot inkluderende læringsmiljø og elevers opplevelse av tilhørighet (Ogden, 2012; Kinsella \& Junior, 2008; Cole, Visser \& Daniels, 2001). God klasseledelse er ikke fravær av all uro og negativ atferd, men det betyr at læreren har effektive strategier for å stoppe uønsket 
atferd når den oppstår. Når klasseledelse fungerer, vil det være færre konflikter, smidigere overganger mellom aktiviteter, kommunikasjon preget av respekt og støtte, og responser tilpasset elevenes behov (Ogden 2012).

Gode klasseledere er også til enhver tid oppmerksomme på hva som foregår i alle delene av klasserommet, de har innsikt i elevenes vennskapsrelasjoner og er opptatt av elevenes friminuttaktiviteter. Dette fører til en bevisst pedagogisk praksis, der for eksempel gruppesammensetninger ikke er tilfeldige, men gjennomtenkte. I grupper der det er stor grad av mestringsmuligheter, vil også de elevene som er mer sårbare enn andre, i langt større grad ha mulighet til opplevelse av tilhørighet både i og utenfor klasserommet. Mestring sammen med andre legger grunnlaget for gode relasjoner og opplevelsen av tilhørighet, som igjen beskytter mot mobbing (Aviles m.fl, 2006). Gode klasseledere er opptatt av å ta elevene på fersk gjerning i å gjøre noe bra, og vektlegger positive tilbakemeldinger som en sentral del av klasseledelsen. Dette gjelder den som mobber, like mye som den som mobbes.

\section{Oppsummerende refleksjon}

Folkehelsearbeid defineres som samfunnets innsats for å påvirke faktorer som direkte eller indirekte fremmer befolkningens helse og trivsel (Folkehelseinstituttet, 2014). Når forskning bekrefter at barn og unge utsettes for mobbing hver dag, og at konsekvensene av mobbing kan settes i sammenheng med svekket helse og livsmestring, er forståelsen av mobbing helt sentral med tanke på hvilke tiltak som iverksettes (Kaltiala-Heino, Rimpela, Rantanen \& Rimpela, 2000). Dersom man kun retter søkelyset mot det enkelte barn og den enkelte unges atferdsuttrykk, leter etter individuelle årsaksforklaringer og forstår mobbing som noe som må ha skjedd et visst antall ganger over en viss tidsperiode, kan tiltakene i forebyggende arbeid bli lite effektive. Mobbing handler, i vår forståelse, om sammensatte sosiale prosesser. De sosiale prosessene må dernest forstås, og det må handles ut fra de kontekstuelle og relasjonelle faktorene som er en del av elevenes læringsmiljø.

I helsefremmende skoler er alle voksne bevisst den avgjørende rollen de har som rollemodeller for barn og unge. De er aktivt med på forebyggende arbeid, de griper inn når de ser mobbing skje, enten det er fra kollegaer eller elever. De lytter til elevene sine, selv når de ikke forstår eller har sett det som har skjedd, og de handler på bakgrunn av elevenes subjektive opplevelser. Kun da vil elevens medvirkning og livsmestring muliggjøres.

Inkluderende læringsmiljøer er en del av den helsefremmende skoles hovedmålsetting, der den enkelte opplever seg som en betydningsfull deltaker i et fellesskap. For å kjenne seg betydningsfull må en få erfaring i å bli hørt, sett og tatt på alvor. Først da kan den enkelte våge å feile, øve seg, prøve igjen, mestre, delta og bidra inn i fellesskapet. 


\section{Om forfatterne}

Ingrid Lund er professor i spesialpedagogikk og arbeider ved Pedagogiske Utviklingssenter ved Universitetet i Agder. Hennes forskningsfelt er bredt og inkluderer barn og unges atferdsutfordringer knyttet til barnehage- og skolekontekst med særskilt fokus på det psykososiale læringsmiljøet.

Institusjonstilknytning: Universitetet i Agder, Pedagogisk utviklingssenter, Serviceboks 422, 4604 Kristiansand

Epost: ingrid.lund@uia.no

Anne Helgeland er senior forsker og familieterapeut ved avdeling for barn og unges psykiskehelse ved Sørlandet sykehus, Kristiansand. Forskningsinteresser er i landskapet av samfunnets syn på barn og beskyttelse av barns rettigheter, og inkluderer tema som mobbing i barnehagen, mobbing i skole, barns deltakelse i familieterapi og samspill voksnebarn.

Institusjonstilknytning: Avdeling for barn og unges psykiske helse, Sørlandet sykehus, Postboks 416, 4604 Kristiansand, Norway

Epost: anne.helgeland@sshf.no

Velibor Bobo Kovac er professor i pedagogisk psykologi ved Institutt for pedagogikk, Universitet i Agder. Hans forskningsprofil er bred og inkluderer tema som motivasjon, læring, avhengighet, mobbing og selvregulering. Institusjonstilknytning: Universitet i Agder, Institutt for Pedagogikk, serviceboks 422, 4604, Kristiansand

Epost: bobo.kovac@uia.no

\section{Referanser}

Anderman, E. M. (2002). School effects on psychological outcomes during adolescence. Journal of Educational Psychology, 94(4), 795-809.

Andreassen, B-O, (2016): Religionsdidaktikk. En innføring. Oslo: Universitetsforlaget.

Arseneault, L., Walsch, E., Trzesniewski, K., Newcombe, R., Caspi, A., Moffitt,T. (2006).

"Bullying victimization uniquely contributes to adjustment problems in young children: a nationally representative cohort study." Pediatrics 118(1), 130-138

Ainsworth, M. D. S. (1967). Infancy in Uganda: Infant care and the growth of love.

Baltimore, MD: Johns Hopkins Press.

Aviles, A. M., Anderson, T. R. \& Davila, E. R. (2006). Child and Adolescent SocialEmotional Development Within the Context of School. Child and Adolescent Mental Health, 11(1), 32-39.

Bang, H. (2013). Organisasjonskultur: En begrepsavklaring. Tidsskrift for Norsk Psykologforening, 50, 326-336.

Barneombudet. (2014). Barneombudets innspill til den nye folkehelsemeldingen i 2015. Oslo. 
Beardslee, W. R., Chien, P. I. \& Bell, C. C. (2011). Prevention of Mental Disorders, Substance Abuse and Problem Behaviors: A Developmental Perspective. Psychiatric Services, 62(3), 247-154.

Baumeister, R., \& Leary, M. R. (1995). The need to belong: Desire for interpersonal attachments as a fundamental human motivation. Psychological Bulletin, 117, 497-529.

Bergem, T. (1998). Lereren i etikkens motlys. Oslo: Ad Notam Gyldendal.

Bowlby, J. (1969). Attachment and loss: Vol 1. Attachment. New York.

Bowlby, J. (1973). Attachment and loss: Vol. 2. Separation: Anxiety and anger. New York.

Cassidy, J., \& Shaver, P. R. (2008). Handbook of attachment: Theory, research, and clinical applications (2nd ed.). New York: The Guilford Press.

Cobb-Roberts, D., Dorn, S. \& Shircliffe, B. J. (2006). Schools as imagined communities: the creation of identity, meaning, and conflict in U.S. history. New York: Palgrave Macmillan.

Cole, T., Visser, J., \& Daniels, H. (2001). Emotional and behavioural difficulties in mainstream schools. Amsterdam: JAI.

Delfabbro, A., Winefield, T., Trainor,S., Dollard,M., Anderson,S., Metzer, J., Hammarstrom, A. (2006). Peer and teacher bullying/victimization of South Australian secondary school students: Prevalence and psychosocial profiles. British Journal of Educational Psychology, 76(1), 71-90.

Drugli, M. B. (2012). Relasjonen lcerer og elev: avgjørende for elevenes læering og trivsel. Oslo, Cappelen Damm Høyskoleforlag.

Fekkes, M., Pijpers, F.I.M., Verlove-Vanhorick, S.P. (2005). Bullying: who does what, when and where? Involment of children, teachers and parents in bullying behavior. Health Educational Research, 20(1), 81 - 91.

Folkehelseinstituttet. (2014). Helsetilstanden i Norge, Oslo

Fosse, G. K. (2006). Mental health of psychiatric outpatients bullied in childhood.

Frisen, A., Holmqvist, K., \& Oscarsson, D. (2008). 13-year-olds' perception of bullying: Definitions, reasons for victimisation and experience of adults' response. Educational Studies, 34(2), 105-117.

Gadner, W. L., Gabriel, S., \& Diekman, A. (2000). The psychophysiology of interpersonal processes. In J. T. Cacioppo, L. G. Tassinary, \& G. G. Bertson (Eds.), The handbook of psychophysiology (2nd ed., 643-664). Cambridge, MA: Cambridge University Press.

Gladden, R.M., Vivolo-Kantor, A.M., Hamburger, M.E., \& Lumpkin, C.D. (2014) Bullying Surveillance Among Youths: Uniform Definitions for Public Health and Recommended Data Elements, Version 1.0. Report, Atlanta, GA; National Center for Injury Prevention and Control, Centers for Disease Control and Prevention and U.S. Department of Education.

Hesedirektoratet (2017): Psykisk helse og livsmestring i skolen. Hentet 05.07-2017 fra: https://helsedirektoratet.no/folkehelse/psykisk-helse-og-rus/psykisk-helse-iskolen/psykisk-helse-og-livsmestring-i-skolen

Herrman, H., Saxena, S. \& Moodie, R. (2005). Promoting Mental Health: Concepts, Emerging Evidence, Practice. Report. Geneva: World Health Organization.

Honeth, A. (2008). Kamp om anerkjennelse. Om de sosiale konfliktenes moralske gramatikk (L. Holm-Hansen, Trans.). Frankfurt am Main / Oslo: Pax Forlag.

Joanson, B., og Flygare, E. (2013). Långvarig utsatthet drabbar hårt. I Skolverket (red) Kränkningar i skolan-analyse og lösningar. Stockholm: Skolverket. Fritzes.

Juul, J., \& Jensen, H. (2002). Pcedagogisk relationskompetence fra lydighed til ansvarlighed. København: Apostrof. 
Kaltiala-Heino, R., Rimpela, M., Rantanen, P. \& Rimpela, A. (2000). Bullying at school--an indicator of adolescents at risk for mental disorders. Journal of Adolescence, 23(6), 661674.

Kaufmann, G., \& Kaufmann, A. (2015). Psykologi i organisasjon og ledelse (5.utg.). Bergen: Fagbokforlaget.

Kinsella, W., \& Senior, J. (2008). Developing inclusive schools: A systemic approach. International Journal of Inclusive Education, 12(5-6), 651-665.

Kooed, J., \& Søndergaard, D. M. (2009). Mobning gentcenkt. København: Hans Reitzels Forlag.

Koač, V. B. (2016). Basic motivation and human behaviour: Control, affiliation and self expression. London, Palgrave McMillan.

Kunnskapsdepartementet (2005) Læreplanverket i KRLE (RLE1-02). Oslo: Utdanningsdirektoratet. Hentet fra http://data.udir.no/kl06/RLE1-02.pdf

Kunnskapsdepartementet. (2015). Å høre til : virkemidler for et trygt psykososialt skolemiljø : utredning fra utvalg oppnevnt ved kongelig resolusjon 9. august 2013 : avgitt til Kunnskapsdepartementet 18. mars 2015 Vol. NOU 2015:2.

Landsrådet for Norges barne- og ungdomsorganisasjoner (2017). Livsmestring i skolen: For flere små og store seiere i hverdagen. Oslo.

Lund, I., Ertesvåg, S., \& Roland, E. (2010). Listening to shy voices: Shy adolescents' experiences with being bullied at school. Journal of Child \& Adolescent Trauma, 3(3), $205-223$.

Milkie, M. A. \& Warner, C. H. (2011). Classroom learning environments and the mental health of first grade children. Journal of Health and Social Behavior, 52(1), 4-22.

Møer, Eggen, Fuglestad, Langfeldt, Presthus, Skrøvset, Stjernstrøm og Vedøy (2005). Successful school leadership: the Norwegian case. Journal of_Educational Administration, 43(6), 584-594.

Leary, M. R. (2011). The sociometer, self-esteem, and the regulation of interpersonal behaviour. In K. D. Vohs \& R. F. Baumeister (eds.) Handbook of self-regulation (pp. 339355). The Guilford Press, London.

Lovdata, (2012). Lov om folkehelsearbeid. Hentet 02.07 fra: https://lovdata.no/dokument/NL/lov/2011-06-24-29?q=folkehelseloven

Modecki, K. L., Minchin, J., Harbaugh, A. G., Guerra, N. G. \& Runions, K. C. (2014). Bullying prevalence across contexts: A meta-analysis measuring cyber and traditional bullying. Journal of Adolescent Health, 55(5), 602-611.

Obegi, J. H., \& Berant, E. (Eds.). (2009). Attachment theory and research in clinical work with adults. New York: Guilford Press.

Ogden, T. (2012). Klasseledelse: Praksis, teori og forskning. Oslo: Gyldendal akademisk.

Olweus, D. (1997). Mobbing i skolen : hva vi vet og hva vi kan gjøre. Oslo: Universitetsforlaget.

Orlofsky, J. L., Marcia, J. E., \& Lesser, I. M. (1973). Ego identity status and the intimacy versus isolation crisis of young adulthood. Journal of Personality and Social Psychology, 27, 211-219.

Riby, K. (2007). Bullying in schools: And what to do about it: Aust Council for Educational Research. Report.

Roland, E. (1983). Strategi mot mobbing. Oslo: Universitetsforlaget.

Roland, E. (2007): Mobbingens psykologi. Hva kan skolen gjøre? Oslo: Universitetsforlaget

Rutter, M. (1997). Psychosocial disturbance in young people. Cambridge: Cambridge University Press.

Rutter, M. (2000). Den livslange udvikling : forandring og kontinuitet (2. udg. utg.). København: Hans Reitzels Forlag. 
Schott, R. M. \& Søndergaard, D. M. (2014). School bullying: New theories in context: Cambridge University Press.

Sandberg, K. (2011). Barns rett til å bli hørt. I Høstmælingen, Kjørholt, Saga., \&

Sadberg, (Red.), Barnekonvensjonen. Barns rettigheter i Norge (s. 77-96). Oslo: Universitetsforlaget.

Slade, A. (2009). The implications of attachment theory and research for adult psychotherapy: Research and clinical perspectives. In J. Cassidy \& P. R. Shaver (Eds.), Handbook of attachment: Theory, research, and clinical applications, 2nd ed., 762-782.

Sourander, A., Ronning, J., Brunstein-Klomek, A., Gyllenberg, D., Kumpulainen, K., Niemelä, S., Tamminen, T. (2009). Childhood bullying behavior and later psychiatric hospital and psychopharmacologic treatment: findings from the Finnish 1981 birth cohort study. Archives of general psychiatry, 66(9), 1005-1012.

Statistisk Sentralbyrå (2017, 20 august). Nøkkeltall for utdanning. Hentet 20. august 2017 fra: https://www.ssb.no/utdanning/nokkeltall

Stortingsmelding nr 28 (2015-2016). Fag-Fordypning-Forståelse; En fornyelse av Kunnskapsløftet. Det Kongelige Kunnskapsdepartement, Oslo.

Søndergaard, D. M. (2012). Bullying and social exclusion anxiety in schools. British Journal of Sociology of Education, 33(3), 355-372.

Ttofi, M. M., Farrington, D. P., Lösel, F. \& Loeber, R. (2011). The predictive efficiency of school bullying versus later offending: A systematic/meta-analytic review of longitudinal studies. Criminal Behaviour and Mental Health, 21(2), 80-89.

Twemlow, S. (2005). The prevalence of teachers who bully students in schools with differing levels of behavioral problems. American Journal of Psychiatry, 162(12), 2387-2389.

Twemlow, S., Fonagy, P., Sacco, F. C., \& Brethour, J.R. (2006). Teacher who bully students: A hidden trauma. International Journal of Social Psychiatry, 52(3),187-198.

Vailancourt, T., et al. (2003). Bullying is power: Implications for school-based intervention strategies. Journal of Applied School Psychology 19(2), 157-176.

Wendelborg, C. (2016). Mobbing, krenkelser og arbeidsro i skolen. Analyse av Elevundersøkelsen skoleåret 2015/2016. NTNU, Trondheim. 